\title{
Stanje i perspektive laikata u postsinodskom vremenu - s posebnim osvrtom na vjeroučitelje laike
}

\author{
IGOR JAKOBFI* \\ • https://doi.org/10.31823/d.27.1.2 • \\ UDK: 27-722.7-733(397.5 Đakovo)*37 • Pregledni članak \\ Primljeno: 30. srpnja 2018. • Prihvaćeno: 12. ožujka 2019.
}

${ }^{*} \mathrm{Mr}$. sc. Igor Jakobfi,

Katolički bogoslovni

fakultet u Đakovu

Sveučilišta J. J.

Strossmayera u Osijeku, P. Preradovića 17, p. p. 54, 31400 Đakovo, Hrvatska, ijakofi@gmail.com

Sažetak: Rad je nastao u okviru proslave desete godišnjice objave Izjava i odluka Druge biskupijske sinode đakovačke i srijemske kao odgovor na sinodske želje: da svaki član $i$ župna zajednica Crkve đakovačke i srijemske postanu svjesniji vlastitoga identiteta; da Crkva đakovačka i srijemska svoje poslanje ostvari po mnoštvu različitih oblika suodgovornoga služenja svih krštenika; da Crkva dakovačka i srijemska otvori prostore suodgovornosti u svom krilu. U radu se na temelju rezultata ankete provedene medu vjeroučiteljima laicima traga za odgovorima na pitanja: Koliko je Druga biskupijska sinoda zaživjela u svijesti i djelovanju vjeroučitelja laika? Kakav je današnji vjeroučiteljski potencijal s kojim Nadbiskupija raspolaže u perspektivi budućih pastoralnih programa? Kako bismo na temelju tih odgovora mogli izraditi inicijalni operativni okvir? Što je potrebno učiniti u narednih deset godina kako bi se dodatno doprinijelo ostvarenju željene sinodske obnove? U prvom dijelu rada predstavljeno je da biti vjeroučitelj jest prije svega životni poziv, a tek drugotno profesija. Medutim u drugom dijelu rada prikazuje se manjak dobro programirane $i$ organizirane strukturne skrbi za njegovanje i rast toga poziva na području prihvaćanja sinodskih zahtjeva za obnovom pastorala, što je dovelo do toga da su Sinoda i njezini pastoralni zahtjevi ostali medu velikim brojem vjeroučitelja neupoznata, a posljedično i neprihvaćena stvarnost. $U$ trećem dijelu, a na tragu neupoznatosti i neprihvaćenosti sinodskih zahtjeva analizira se stanje konkretnih područja pastoralnoga interesa 
i pastoralnih aktivnosti vjeroučitelja i to posebno sljedeća područja: brak i obitelj, mediji, ekumenizam, kultura, socijalni nauk Crkve, intelektualci te stari/bolesni/invalidi. $U$ četvrtom dijelu rada analizira se uključenost vjeroučitelja $u$ rad triju vrsta struktura suodgovornosti, župna pastoralna vijeća, župne skupine i vjernička društva te konkretno volontersko zalaganje, njegova ograničenja i mogućnosti. Rad završava praktičnim preporukama koje trebaju Nadbiskupija, svećenici i laici (studenti teologije, nezaposleni teolozi i vjeroučitelji) ostvariti na području jačanja struktura suodgovornosti kako bi se dvadeseta godišnjica Sinode proslavila u pastoralno obnovljenom ozračju.

Ključne riječi: Druga biskupijska sinoda, vjeroučitelji laici, laici, strukture suodgovornosti.

\section{Uvod i metodološke napomene}

Dvadeseta godišnjica od sazivanja Druge biskupijske sinode đakovačke i srijemske i deseta od objave sinodskih izjava i odluka Ti si Krist - za nas i za sve ljude jest neizostavna prigoda za analizu aktualnoga stanja naše Nadbiskupije u odnosu na sinodske zahtjeve/očekivanja te izradu predviđanja i preporuka za pastoralno planiranje i razvoj u narednim desetljećima. No to nije samo puka slavljenička prigoda već i sinodska obveza na koju posredno ukazuje i sama Sinoda izrazivši smjer zacrtane pastoralne obnove trima željama ${ }^{1}$ : da svaki član i župna zajednica Crkve đakovačke i srijemske postanu svjesniji vlastitoga identiteta; da Crkva đakovačka i srijemska svoje poslanje ostvari po mnoštvu različitih oblika suodgovornoga služenja svih krštenika te da Crkva đakovačka i srijemska otvori prostore suodgovornosti u svom krilu. ${ }^{2}$ Bitne dimenzije ostvarenja tih triju želja jesu i dvije obveze: istražiti u kolikoj su se mjeri u posljednjem desetljeću one uistinu ostvarile te što je još potrebno činiti kako bi se i dalje sinodske želje u što većoj mjeri ostvarivale.

Premda su sinodski zahtjevi obvezujući i upućeni cijeloj mjesnoj Crkvi, ipak, nemoguće je ne uočiti kako postoje konkretni praktični razlozi koji objektivno priječe očekivanje njihova olaka ostvarenja kod ukupne populacije krštenika. Pri tome ponajprije mislimo na vjernike laike, točnije njihovu heterogenost u odnosu na upoznatost sa sadržajima i zahtjevima vjere te konkretnoga praktičnoga iskustva i življenja vjere. Jedno je samo nominalno biti kršćanin (laik) ${ }^{3}$; a drugo je biti laik na

\footnotetext{
${ }^{1}$ Usp. Ti si Krist - za nas i za sve ljude. Izjave i odluke Druge biskupijske sinode dakovačke i srijemske, Đakovo, 2008. (= Izjave i odluke), br. 22.

${ }^{2}$ Usp. isto, br. 1 i 249.

${ }^{3}$ Ovdje se služimo postojećom, ali za potrebe ovoga rada u određenim dijelovima prilagođenom klasifikacijom vjernika u hrvatskom društvu. Za dodatna pojašnjenja pojedinih dimenzija klasifikacije vidi: P. ARAČIĆ, G. ČRPIĆ, Z. PAŽIN, K. VIŠATICKI, I. DŽINIĆ, Kršćanski identitet i obitelj, u: Vjesnik Đakovačko-osječke nadbiskupije i Srijemske biskupije 139(2011.)6, 585.
} 
temelju obiteljskoga, nacionalnoga i/ili kulturnoga nasljeđa koji je malo ili nimalo poučen u vjeri; Treće, biti poučen u vjeri u okviru više ili manje sustavne župne kateheze i više ili manje redovito sakramentalno živjeti; Četvrto, biti zreo odrastao laik koji je duboko i iskreno uronjen u Boga, redovito živi sakramentalni život, a od kojih je određen broj na području naše Nadbiskupije završio i Školu za župne suradnike; A sasvim je nešto peto biti zreo odrastao laik koji je završio teološki studij i pri tome je ili će tek biti zaposlen kao vjeroučitelj u školi ${ }^{4}$. Naime vjeroučitelji laici jesu prvi od kojih se može i mora očekivati da postanu svjesniji vlastitoga identiteta i načina njegova ostvarenja te da prepoznaju prostore suodgovornosti kao mjesta osobnoga poziva i načine aktivnoga uključivanja u njih. Oni su prvi od kojih je potrebno započeti analizu stanja i perspektiva laikata u postsinodskom vremenu Đakovačko-osječke nadbiskupije jer, ako njima nisu poznati, razumljivi i primjenjivi zahtjevi Sinode, koliko tada tek nisu ostalim laicima. Stoga nam je cilj ovim istraživanjem doprinijeti traganju za odgovorima: Koliko je Sinoda zaživjela u svijesti i djelovanju vjeroučitelja laika? Kakav je današnji vjeroučiteljski potencijal s kojim Nadbiskupija raspolaže u perspektivi budućih pastoralnih programa? Kako bismo na temelju tih odgovora mogli izraditi osnovne praktične smjernice što je potrebno učiniti u narednih deset godina kako bi se dodatno doprinijelo ostvarenju željene sinodske obnove.

Kako do sada nije izrađen neki posebni instrument mjerenja ostvarenosti sinodske obnove, za potrebe našega istraživanja izradili smo na temelju sinodskih zahtjeva te teorije o intelektualnom i socijalnom kapitalu anonimni anketni upitnik ${ }^{5}$ za vjero-

\footnotetext{
${ }^{4}$ Ovdje dodatno razlikujemo one koji su završili teološki studij, ali su ih životne okolnosti navele da se profesionalno bave drugim poslovima od onih koji su zaposleni u školi kao vjeroučitelji. $U$ radu proučavamo samo vjeroučitelje jer je kod njih najviše očekivana duboka prožetost osobne vjere $s$ privatnim, društvenim i profesionalnim životom.

${ }^{5}$ Anketni upitnik izradio je autor rada u suradnji s dr. sc. Stanislavom Šotom, profesorom pastoralne teologije na Katoličkom bogoslovnom fakultetu u Đakovu i koordinatorom Pastoralnoga centra Đakovačko-osječke nadbiskupije koji je svojim vrsnim poznavanjem sadržaja sinodskih dokumenata i konkretnih pastoralnih poteškoća u ostvarenju sinodske obnove dao velik doprinos u sadržajnom sastavljanju upitnika. Pri sastavljanju upitnika uz Izjave i odluke Druge biskupijske sinode đakovačke i srijemske u obzir su uzeti aktualni znanstveni zaključci o važnosti i značaju intelektualnoga kapitala, a posebno u njegovoj dimenziji ljudskoga i strukturalnoga kapitala kao znanstveno utemeljenoga i široko korištenoga koncepta za analizu postojećega stanja i poboljšanja učinkovitosti ostvarenja zadanih ciljeva organizacija. Također je u obzir uzet i koncept socijalnoga kapitala kao odlika društvenih organizacija izražena povjerenjem, normama i mrežama koje mogu poboljšati učinkovitost olakšavanjem koordiniranih akcija. Koristili smo se alatom World Giving Indeks za mjerenje raspoloživosti za solidarnost s drugima, koji je razvila Charities Aid Fundation, te neka već gotova pitanja iz dvaju provedenih istraživanja: Teološko fundiranje solidarnosti u hrvatskom društvu i Supsidijarnost $u$ hrvatskom društvu, koja su po naravi proučavane materije sadržajno bliska sinodskim zahtjevima. Više o intelektualnom kapitalu i socijalnom kapitalu, razlozima korištenja tih koncepta u govoru o
} 
učitelje koji sadržava pedeset i jedno pitanje (četrdeset i devet pitanja zatvorenoga tipa i dva pitanja otvorenoga tipa) s pripadajućim potpitanjima (ukupno 120 varijabli), podijeljeno u četiri kategorije: Opći podatci o anketiranima; Područja pastoralnoga interesa i aktivnosti vjeroučitelja na unutarcrkvenom i civilnom području; Postojeći oblici življenja kršćanskoga zajedništva na području župe prebivanja vjeroučitelja i njihova percepcija kvalitete življenja kršćanskoga zajedništva; Vjeroučiteljske osobne navike permanentne edukacije. Važno je istaknuti kako ciljana skupina istraživanja nije bila ukupna vjeroučiteljska populacija, već samo onaj dio od kojega se može očekivati da je tijekom teološke formacije mogao biti teološki dublje upoznat $s$ aktualnom Sinodom i institutom sinode, to jest da je studirao u vremenu sazivanja, tijekom ili poslije Sinode te je tako više ili manje aktivno/pasivno uključen u tijek njezina održavanja i/ili provođenja njezinih zahtjeva u djelo. Time je prema kriteriju starosti određeno da ciljana populacija ne bi trebala biti starija od 45 godina $^{6}$ (tijekom 2018. godine), odnosno upravo ona skupina s kojom je još moguće planirati i u djelo provesti ozbiljne dugoročne pastoralne planove. Anketa je provedena mrežno ispunjavanjem Google Forms obrasca tijekom siječnja 2018.

stanju i perspektivama laikata u postsinodskom vremenu te o spomenutim provedenim istraživanjima i World Giving Indexu vidi u: J. JURCZAK, Intellectual Capital Measurement Methods, u: Economics and organization of enterprise 1(2008.), 37-45.; D. SUNDAĆ, D. ŠKALAMERA - ALILOVIĆ, M. BABIĆ, Poslovno okružje i intelektualni kapital, Rijeka, 2016.; I. JAKOBFI, Intelektualni kapital - mogućnost povratka vjere u hrvatsku javnost u: Vjesnik Đakovačko-osječke nadbiskupije i Srijemske biskupije 140(2012.)1-2, 31-39.; R. D. PUTMAN, Kako demokraciju učiniti djelotvornom, Fakultet političkih znanosti, 2003.; B. ŠALAJ, Koncept socijalnog kapitala u komparativnoj politici, u: Politička misao 40(2003.)4, 126-144.; A. ALIBAŠ́Ć, Društveni kapital i održivi razvoj, u: Zbornik radova Fakulteta islamskih nauka (2005.)10, 297-314.; I. JAKOBFI, Socijalni kapital u Crkvi, u: Vjesnik Đakovačko-osječke nadbiskupije i Srijemske biskupije 140(2012.)7-8, 558-566.; S. BALOBAN, G. ČRPIĆ, M. KOMPES, Centar za promicanje socijalnog nauka Crkve. Deseta obljetnica djelovanja (1998. - 2008.), Zagreb, 2008., 140-152.; S. BALOBAN, Ostvarivanje solidarnosti po supsidijarnosti, u: Bogoslovska smotra 75(2006.)4, 1019-1043.; G. ČRPIĆ, D. MRAVUNAC, Pregled postotaka istraživanja »Supsidijarnost u hrvatskom društvu «, u: Bogoslovska smotra 81(2012.)4, 731-752.; www.cafonline.org (12.12. 2017.) Prikupljanje i jedan dio statističke obrade podataka učinjeni su uz pomoć aplikacije Google Forms, koju preporuča Carnet kao alat za izradu mrežnih anketa, upitnika ili kvizova, a omogućuje kreiranje neograničene količine formi te pregled i statističku analizu odgovora. Više o Google Forms vidi u: http://e-laboratorij.carnet.hr (12. 1. 2019.)

${ }^{6}$ Više o mlađoj populaciji kao angažiranijoj u aktivnom sudjelovanju u izgradnji općega dobra u odnosu na stariju populaciju vidi u: S. ZRINŠĆAK, Mlađi i obrazovaniji ljudi spremniji su se angažirati za opće dobro, u: Civilno društvo 2(2005.)5, 7-11. Više o odnosu starosne dobi i radne produktivnosti koja vrhunac doživljava u 44./45. godini života vidi u: S. BRUNOW, G. HIRTE, Age Structure and Regional Economic Growth, u: Jahrbuch für Regionalwissenschaft 26(2006.)3, 3-23.; A. KUNNERT, P. MAYERHOFER, D. PENNERSTORFER, Demographischer Wandel und regionale Produktivitätsentwicklung in Österreich, u: WIFO - Monatsberichte 85(2012.)11, 863-874. 
godine koji je e-poštom poslan svim vjeroučiteljima ${ }^{7}$ koji ulaze u ciljanu skupinu, a pri čemu je u obrascu isključena mogućnost prikupljanja osobnih podataka te je tako zajamčena anonimnost. Rezultati ankete obrađeni su metodom izračuna aritmetičke sredine i frekvencije uz pomoć aplikacija Google Forms, Excel 2016 i Access 2016. Od ukupnoga broja vjeroučitelja koji pripadaju ciljanoj skupini na anketiranje je pristalo njih 75 (1/3) od kojih je 73,3\% ženskih, 26,7 \% muških, što ujedno i odgovara stvarnoj razdiobi vjeroučitelja prema spolu. Anketom su podjednako obuhvaćeni vjeroučitelji skoro svih dobnih skupina unutar ciljane skupine (od 23 do 25 - 5,3\%; od 26 do 30 - 20,0 \%; od 31 do 35 - 26,7 \%; od 36 do $40-22,7 \%$; od 41 do $45-25,3 \%)$. Vjeroučitelji između 23 i 25 godina starosti najmanje su pristali na anketiranje. Riječ je o vjeroučiteljima koji su tek završili teološki studij i kojih je trenutačno najveći broj nezaposlenih. Mnogi od njih na primljenu anketu odgovorili su ovim ili sličnim riječima: »Nemam ništa protiv ovakvih anketa, ali ne vidim nikakvu svrhu u njihovom popunjavanju kada mi ionako neće riješiti glavni životni problem - nezaposlenost.« Tako su ujedno i sami pojasnili izostanak sudjelovanja u anketiranju.

\section{Biti vjeroučitelj prije svega je životni poziv}

Uciteljsko zanimanje smatra se jednim od najstresnijih i emocionalno najzahtjevnijih zanimanja uopće. O tome svjedoči i trend napuštanja učiteljskoga posla zadnjih nekoliko desetljeća ${ }^{8}$. Pridaju li se tomu i nerijetki zlonamjerni javni napadi na Crkvu i njezine službenike, tada bi se moglo očekivati da će značajan broj vjeroučitelja izraziti nezadovoljstvo vlastitim vjeroučiteljskim pozivom i želju za promjenom zanimanja. Međutim anketni rezultati upravo pokazuju suprotne stavove. Prosječna ocjena kojom su ispitanici ocijenili vlastito zadovoljstvo vjeroučiteljskim pozivom iznosi $4,1^{9}$. Najveći je broj onih koji zadovoljstvo ocjenjuju ocjenama pet $(41,3 \%)$ i četiri (37,3\%), a najmanji broj ocjenama jedan (1,3\%), dva (5,3\%) i tri (14,6\%). Unutar skupine onih koji su zadovoljstvo ocijenili jedinicom i dvojkom 20,0 \% je stalno zaposlenih, a 80,0 \% privremeno zaposlenih i nezaposlenih. Stalno zaposleni koji su ocijenili ocjenama jedan i dva čine tek $1,9 \%$ od ukupnoga broja stalno zaposlenih, privremeno zaposleni $11,1 \%$, a nezaposlenih 23,0 \%. Uzme li se u obzir da je među anketiranima najčešće riječ o vjeroučiteljima koji imaju obitelj, može

\footnotetext{
${ }^{7}$ Podatke o broju, spolu, starosti i e-adresama vjeroučitelja laika dobili smo od Katehetskoga ureda i Središnje nadbiskupijske i fakultetske knjižnice.

${ }^{8}$ Usp. C. M. BROTHERIDGE, A. A. GRANDEY, Emotional labor and burnout: Comparing two perspectives of $\gg$ people work «, u: Journal of Vocational Behavior 60(2002.)1, 17-39.; I. MACUKA, I. BURIĆ, Emocionalne odrednice iscrpljenosti i zadovoljstva poslom predmetnih učitelja, u: Društvena istraživanja 26(2017.)2, 227-248.
}

\footnotetext{
${ }^{9}$ Najmanja je ocjena 1 , a najveća 5.
} 
se pretpostaviti da je prisutnost nezadovoljstva daleko više uzrokovana nesigurnošću u ostvarenju temeljnih materijalnih preduvjeta za život nego razočaranošću u vjeroučiteljski poziv kao takav. Tu će tvrdnju dodatno potkrijepiti podatci o želji za promjenom zanimanja jer skoro polovica od svih vjeroučitelja, njih 46,6\%, nije ni jednom poželjela promijeniti zanimanje, jednom je poželjelo njih $8,0 \%$, dva do tri puta $16,0 \%$, četiri puta $14,6 \%$, a isti je udio i onih koji o tome stalno razmišljaju (14,6\%). Razloge koji dovode do želje za promjenom zanimanja moguće je raspodijeliti u tri skupine ${ }^{10}$, a dominira nesigurnost zaposlenja (46,1\%), a tek drugotno navodi se razočaranost vjeroučiteljskim pozivom $(26,9 \%)$ i manjak privatnosti $(26,9 \%)$. Na temelju rečenoga možemo s velikom nadom i optimizmom ustvrditi kako biti vjeroučitelj u svijesti naših vjeroučitelja nije samo tek puko zanimanje koje jamči materijalnu sigurnost, jer određenom broju trenutačno ni ne jamči, već egzistencijalno značajan poziv koji uz prisutnost određenih objektivnih poteškoća ipak životno ispunjava.

\section{Sinoda - neupoznata i neprihvaćena stvarnost $s$ velikim potencijalom upoznavanja i prihvaćanja}

Premda je od sazivanja Sinode do danas prošlo dvadeset godina, premda su u njezinim pripremnim savjetovanjima sudjelovali i mnogi današnji vjeroučitelji, premda su njezine odluke obvezujuće za sve članove mjesne Crkve, vjeroučitelji nisu prihvatili njezine Izjave i odluke, što začuđuje. Od ukupnoga broja anketiranih vjeroučitelja njih čak 69,4\% malo/nimalo ne prihvaća njezine Izjave i odluke. Ne možemo ne zapitati se zašto je tako. Kako to da odluke najvećega pastoralnoga događaja jedne biskupije prihvaća tek $1 / 3$ njezinih pastoralno najaktivnijih laika? Rezultati provedene ankete upućuju da bi razloge trebalo tražiti u mjeri upoznatosti sa sinodskim Izjavama i odlukama te u izvorima upoznavanja s njima. Raspodjelom vjeroučitelja prema stupnju prihvaćenosti sinodskih Izjava $i$ odluka u dvije skupine, na one koji ih dosta/potpuno prihvaćaju i na one koji ih djelomično/nimalo ne prihvaćaju, uočavamo međupovezanost mjere upoznatosti s mjerom prihvaćenosti. Od ukupnoga broja vjeroučitelja koji su Izjave $i$ odluke dosta/potpuno upoznali $68,4 \%$ ih i dosta/potpuno prihvaća i obratno, od ukupnoga broja onih koji su ih malo/nimalo upoznali čak 88,0 \% ih djelomično/ nimalo prihvaća. Toj međupovezanosti mjere prihvaćenosti i mjere upoznatosti treba pristupiti kao važnom polazištu u budućem pastoralnom planiranju jer postoji velika vjerojatnost da bi sinodski zahtjevi bilo daleko bolje prihvaćeni, a posljedično tomu i provedeni u djelo kada bi se na primjeren način vjeroučitelji,

\footnotetext{
${ }^{10}$ Vjeroučiteljima u tom anketnom pitanju odgovori nisu bili ponuđeni, već im je ostavljeno da sami u nekoliko riječi objasne razloge zbog kojih su poželjeli promijeniti zanimanje.
} 
ali, dakako, i ostali laici s njima upoznali. Sinodske su Izjave i odluke dosta/potpuno prihvaćene kod najvećega broja onih vjeroučitelja koji su se s njima upoznali samostalno (37,9\%), zatim slijede oni koje su upoznali župnici $(33,3 \%)$, studij teologije $(31,2 \%)$ te na posljednjem mjestu permanentna edukacija vjeroučitelja (21,7 \%). Nažalost, od ukupnoga broja vjeroučitelja tek njih $25,3 \%$ smatra da su se s Izjavama i odlukama dosta/potpuno upoznali. Najzastupljeniji izvori upoznavanja ${ }^{11}$ jesu studij teologije $(49,2 \%)$ i/ili samostalni rad $(44,6 \%$,). Nešto je manje onih koji navode permanentnu edukaciju vjeroučitelja $(35,4 \%)$, a samo njih $18,5 \%$ navode da su se s njima upoznali preko župnika. Za svaku je pohvalu i vrlo je velik pastoralni potencijal za našu Nadbiskupiju da je skoro polovina vjeroučitelja koji su Izjave i odluke upoznali to učinila samostalnim radom te su tako pokazali primjerenu osviještenost o nužnosti samostalne permanentne edukacije. Dodatni pokazatelj da su vjeroučitelji svjesni nužnosti permanentne edukacije jesu i odgovori na pitanje o praćenju novoizdanih crkvenih dokumenata. Uopće ne prati novoizdane dokumente $22,7 \%$ vjeroučitelja, prati samo one koji ih tematski zanimaju $60,0 \%$, a prati sve dokumente $17,3 \%$. Svaki od izvora upoznavanja Izjava i odluka sam u sebi sadrži velik i nezamjenjiv potencijal u promicanju sinodske obnove. Međutim doprinos koji mogu pružiti ne ovisi samo o njima kao takvima već i u velikoj mjeri o percepciji povjerenja u njih od onih spram kojih su usmjereni jer što je viša razina povjerenja, veća je vjerojatnost suradnje, a suradnja povratno rađa povjerenjem ${ }^{12}$, u našem slučaju učinkovitijim komuniciranjem sinodskih zahtjeva. Vjeroučitelji najveće povjerenje imaju u kolege vjeroučitelje (mnogo/dosta - 64,1\%; do određene mjere - 29,3\%; nimalo - 6, 6\%), zatim u župnika (mnogo/dosta - 61,3\%; do određene mjere - 31,0\%; nimalo $-6,7 \%$ ), župljane koje susreću na misi (mnogo/dosta - 61,2\%; do određene mjere - 31,9\%; nimalo - 6,9\%.) te u ostale župljane (mnogo/dosta - 40,3\%; do određene mjere - 52,7\%; nimalo - 7,0\%). Povjerenje koje vjeroučitelji iskazuju spram kolega vjeroučitelja i župnika velik je pastoralni potencijal, ali još uvijek nedovoljno iskorišten. Naime vjeroučitelji su vrlo često i sami predavači na vjeroučiteljskim permanentnim edukacijama te su kao takvi vrlo pogodni za svjedočenje i oduševljenje drugih za sinodsku obnovu. Stoga je potrebno u budućnosti stvarati više prostora u okviru permanentne edukacije vjeroučitelja za one teme u okviru kojih će vjeroučitelji moći dodatno pozitivno doprinijeti upoznavanju i ostvarenju sinodske obnove kod drugih vjeroučitelja na temelju vlastitih autentičnih pastoralnih iskustava. Dok su ostali izvori upoznavanja više ili manje specifični samo za vjeroučitelje, jedino su župnici izvor koji je zajednički i vjeroučiteljima i ostalim laicima. Zbog toga podatci o župnicima kao izvorima u

\footnotetext{
${ }^{11}$ Vjeroučiteljima je ostavljena mogućnost da navedu više izvora upoznavanja.

${ }^{12}$ Usp. R. D. PUTNAM, Kako demokraciju učiniti djelotvornom, Zagreb, 2003., 183.
} 
komuniciranju sinodskoga učenja dodatno zabrinjavaju, ali istodobno i ukazuju na njihov velik, ali još uvijek nedovoljno iskorišten potencijal. Može se pretpostaviti da su upravo vjeroučitelji sa župom najpovezaniji i sa župnim pastoralnim programima najupoznatiji. Odnosno, teško je povjerovati da bi se na razini župe događalo nešto pastoralno značajnije tijekom duljega razdoblja, poput ozbiljno pripremljene i provedene sinodske obnove, a da to vjeroučitelji kao katehete ili članovi župnih vijeća ne znaju. Stoga se neizostavno moramo zapitati: Ako su župnici bili izvor upoznavanja za manje od $1 / 5$ vjeroučitelja, koliki je tek broj drugih, sa župom više ili manje povezanih, laika koji su preko župnika upoznati s Izjavama i odlukama? Župnici su očito za vjeroučitelje najbliži i najprikladniji izvor u promicanju sinodske obnove, a za opću populaciju laika nerijetko i jedini. Oni su ti koji imaju najveći i najznačajniji utjecaj u oblikovanju laikata te zbog toga od njih i mora započeti svako buduće pastoralno planiranje kako bi sinodska obnova polučila željene rezultate. Ipak, ne treba zaboraviti da u župama uz župnika veliku pastoralnu ulogu imaju i vjeroučitelji. Veliko povjerenje koje vjeroučitelji iskazuju spram onih župljana koje susreću na misi ukazuje na postojanje intimno povezanih euharistijskih zajednica, što je itekako poželjna stvarnost za uspješno vjeroučiteljsko provođenje sinodske obnove na području naših župa.

Manjak dobro programirane i organizirane strukturne skrbi za njegovanje i rast vjeroučiteljskoga poziva na području prihvaćanja sinodskih zahtjeva za obnovom dovela je do toga da su Sinoda i njezini pastoralni zahtjevi ostali nepoznati među velikim brojem vjeroučitelja, a zasigurno i ostalih laika, te posljedično i neprihvaćena stvarnost.

\section{Područja pastoralnoga interesa i pastoralnih aktivnosti vjeroučitelja}

Sinoda je posebno istaknula da nijedan oblik kateheze ne može postići da Crkva đakovačka i srijemska sve više živi zajedništvo suodgovornoga naroda Božjega ako se posebna pozornost ne posveti radu s odraslima ${ }^{13}$. U radu s odraslima osobit naglasak treba staviti na rad s obiteljima jer će to stvarati pretpostavke i za veći uspjeh u radu s djecom. ${ }^{14}$ Sinoda ističe i detaljno razrađuje sljedećih sedam prioritetnih pastoralnih područja / posebnih skupina u radu s odraslima: mediji ${ }^{15}$,

\footnotetext{
${ }^{13}$ Usp. Izjave i odluke, br. 22.

${ }^{14}$ Usp. isto, br. 23.

${ }^{15}$ Usp. isto, br. 130-247.
} 
ekumenizam ${ }^{16}$, socijalni nauk Crkve ${ }^{17}, \operatorname{karitas}^{18}{ }^{18}$ kultura $^{19}$, intelektualci ${ }^{20}$ i stari/ bolesni/invalidi ${ }^{21}$.

Zabrinjavajuće je da nasuprot tim sinodskim zahtjevima najveći broj vjeroučitelja $(56,0 \%)$ ističe da im je područje pastoralnoga interesa sakramentalna kateheza i školski vjeronauk, zatim slijede mladi $(37,3 \%)$, karitas (34,6 \%), Biblija (29,3\%), brak i obitelj (29,3\%), misije (20,0\%), duhovnost (20,0\%), mediji (17,3\%), liturgija $(12,0 \%)$, ekumenizam $(12,0 \%)$, a na začelju stoje socijalni nauk Crkve $(6,6 \%)$, kultura $(5,3 \%)$, intelektualci $(4,0 \%)$, ministranti $(4,0 \%)$, branitelji $(2,6 \%)$ i stari/ bolesni/invalidi ( $1,3 \%)$. Nešto bolji, ali još uvijek daleko od očekivanoga jesu odgovori na pitanja: 1 . Za koje ste susrete u organizaciji Nadbiskupije zainteresirani? 2. Na kojim susretima želite aktivno sudjelovati? Najveći broj vjeroučitelja zainteresiran je za braki obitelj $(1-42,3 \% ; 2-29,5 \%)^{22}$, zatim slijede sakramentalna kateheza i školski vjeronauk $(1-40,8 \% ; 2-33,0 \%)$, karitas $(1-38,0 \% ; 2-30,9 \%)$, mladi ( $1-36,6 \% ; 2-29,5 \%)$, Biblija $(1-35,2 \% ; 2-16,9 \%)$, misije $(1-25,4 \%$; $2-18,3 \%)$, duhovnost $(1-25,4 \% ; 2-8,4 \%)$, mediji $(1-22,5 \% ; 2-16,9 \%)$, kultura $(1-16,9 \% ; 2-12,6 \%)$, ekumenizam $(1-15,5 \% ; 2-12,6 \%)$; socijalni nauk Crkve $(1-14,1 \% ; 2-8,4 \%)$, a na začelju stoje liturgija $(1-9,9 \% ; 2-11,2 \%)$, intelektualci $(1-8,5 \% ; 2-7,0 \%)$, branitelji $(1-5,6 \% ; 2-7,0 \%)$, ministranti (1 $-5,6 \% ; 2,8 \%)$ i stari/bolesni/invalidi $(1-4,2 \% ; 2-2,8 \%)$. Na svim područjima, osim na području liturgije i branitelja, primjetna je veća spremnost na pasivno od aktivnoga sudjelovanja, što se zasigurno ne bi trebalo očekivati od vjeroučitelja kao onih koji bi od laika trebali biti prvi nositelji nadbiskupijskoga pastorala. Navedeni podatci za područja pastoralnoga interesa i aktivnosti ne samo da ne prate sinodske zahtjeve već, naprotiv, u određenoj mjeri potvrđuju njezine tvrdnje da se pastoralno djelovanje često sužavalo, da se naglasak stavljao na puko katekizamsko učenje i na dijeljenje sakramenata ${ }^{23}$. Zabrinutost treba biti tim veća jer je prošlo skoro dva desetljeća od kada su se na sinodskim zasjedanjima problemi uočili te jer je riječ o tvrdnjama vjeroučitelja koji su teologiju studirali u vremenu održavanja Sinode ili nakon nje.

\footnotetext{
${ }^{16}$ Usp. isto, br. 218-235.

${ }^{17}$ Usp. isto, br. 165-173.

${ }^{18}$ Usp. isto, br. 203-217.

${ }^{19}$ Usp. isto, br. 191-202.

${ }^{20}$ Usp. isto, br. 12, 28 i 61.

${ }^{21}$ Usp. isto, br. 74-96.

${ }^{22}$ Brojevi ( 1 i 2 ) u zagradama odnose se na prethodna pitanja u tekstu 1. i 2.

${ }^{23}$ Usp. PAVAO VI., Enagelii nuntiandi, Zagreb, 2000., br. 22; Izjave i odluke, br. 8.
} 


\subsection{BRAK I OBITELJ}

Crkva se na poseban način očituje u obitelji. Bračno zajedništvo uprisutnjenje je milosne ljubavi i spasenjskoga životnoga zajedništva između Krista i Crkve tako da je život kršćanske obitelji mjesto ostvarenja Crkve. Obitelj po posvećenju u sakramentu ženidbe ima svoje posebno mjesto i poslanje u izgradnji crkvene zajednice i to ponajprije kao one najmanje u njoj, to jest kućne Crkve ${ }^{24}$. Pastoralno djelovanje Crkve pozvano je kršćanske zaručnike tijekom priprave za ženidbu dovesti do produbljenja dara ljubavi i do iskustva žive vjere ${ }^{25}$, a za to su joj neizostavno potrebni osvjedočeni kršćanski bračni parovi ${ }^{26}$. Podatci o zainteresiranosti za pastoral braka i obitelji otkrivaju kako kod vjeroučitelja zainteresiranost za to područje pastorala opada s porastom dobi. Dobna skupina od 23 do 30 godina starosti sadržava najveći broj zainteresiranih (52,6\%), značajno manje dobna skupina od 31 do 40 $(29,7 \%)$, a izrazito malo dobna skupina od 41 do 45 (5,2\%). Koliko god je pohvalno što su za to područje pastorala zainteresirani mlađi vjeroučitelji, njihov interes je ipak trenutačno pastoralno manje značajan jer je riječ o vjeroučiteljima koji još nisu ili će tek zasnovati brak/obitelj. Ipak, to još ne znači da ih se treba pastoralno zapostaviti, već, naprotiv, u njima treba prepoznati dugoročni pastoralni potencijal $\mathrm{s}$ kojim već danas treba početi sustavno planirati i raditi na aktivnom uključivanju u pastoral braka i obitelji. Istodobno pastoralno je zabrinjavajuće što je zainteresiran vrlo malen broj onih koji već imaju bračnoga i obiteljskoga iskustva te bi kao takvi trebali biti najkompetentniji za svjedočenje o ljepoti i smislu življenja kršćanskoga bračnoga i obiteljskoga zajedništva. Slično kao i kod već predstavljene upoznatosti i prihvaćenosti sinodskih Izjava i odluka i kod pastorala braka i obitelji primjetna je slična međupovezanost. Od ukupnoga broja vjeroučitelja koji su djelomično/ malo upoznati sa sinodskim Izjavama i odlukama njih tek $23,2 \%$ zainteresirani su za pastoral braka i obitelji, a od onih koji su dosta/potpuno upoznati zainteresirano je 47,3 \%. Razlika je još izraženija kada je riječ o mjeri prihvaćenosti. Dok je od ukupnoga broja vjeroučitelja koji djelomično/nimalo prihvaćaju Izjave i odluke za brak i obitelj zainteresirano 17,3\%, od onih koji ih dosta/potpuno prihvaćaju zainteresirano čak 56,5\%. Činjenica da zainteresiranost za pastoral braka i obitelji raste kako raste mjera upoznatosti i prihvaćenosti sinodskih dokumenata jest važno polazište za buduće planiranje pastorala braka i obitelji. Zanimljivo je istaknuti da od ukupnoga broja onih koje su prema izvoru upoznatosti s Izjavama i odlukama s njima upoznali župnici $41,6 \%$ jest zainteresiranih za brak i obitelj. Premda je riječ o poželjnom broju zainteresiranih, ipak ga s oprezom treba tumačiti kao plod ob-

\footnotetext{
${ }^{24}$ Usp. isto, br. 37.

${ }^{25}$ Usp. isto, br. 40.

${ }^{26}$ Usp. isto, br. 43 i 46.
} 
novljenoga pastorala na koji poziva Sinoda jer se u obzir mora uzeti i čimbenik opće crkvene osjetljivosti spram braka i obitelji.

\subsection{Mediji, eKumenizam, Kultura, socijalni nauk Crkve, INTELEKTUALCI I STARI/BOLESNI/INVALIDI}

Zajedničko pastoralu na području medija, ekumenizma, kulture, socijalnoga nauka Crkve intelektualaca i starih/bolesnih/invalida jest $s$ jedne strane veliko značenje koje im je pridala Sinoda i s druge strane izuzetno niska zainteresiranost vjeroučitelja. Uočljiva su određena pastoralno značajna obilježja skupine vjeroučitelja koji spram njih izražavaju interes od kojih je najizraženije sklonost pomaganju drugima koji nisu dio njihove obitelji ili prijatelja. Od ukupnoga broja onih koji su u posljednja dva mjeseca pomogli više od šest puta 38,4 \% izražava interes spram navedenih pastoralnih područja, od onih koji su pomogli pet do šest puta pomogli $62,5 \%$, tri do četiri puta $31,5 \%$, jedan do dva puta $17,6 \%$ i onih koji nisu ni jednom pomogli $0 \%$. Međupovezanost mjere prihvaćenosti Izjava $i$ odluka i zainteresiranosti uočljiva je i kod tih pastoralnih područja. Dok je od onih koji djelomično ili nimalo prihvaćaju zainteresirano samo $25,0 \%$, onih koji Izjave i odluke prihvaćaju potpuno značajno je više $(47,8 \%)$. Potencijal koji se krije u velikom povjerenju u župnike nije dovoljno iskorišten ni na tom području, a što je posebno problematično u odnosu na ostale laike. Od ukupnoga broja onih koje su s Izjavama i odlukama upoznali župnici tek $8,3 \%$ zainteresirano je za ta pastoralna područja. Značajnije je veći udio onih koji su se s Izjavama i odlukama upoznali samostalno (48,2 \%), tijekom studija (40,6 \%) ili tijekom permanentne edukacije vjeroučitelja $(26,0 \%)$ Ipak, koliko god ti izvori upoznavanja bili značajni za vjeroučitelje, nisu, nažalost, primjenjivi na ostale laike.

\section{Vjeroučitelji, premda nedovoljno uključeni u strukture suodgovornosti, ipak su vrlo aktivni}

Sinoda je predvidjela i u određenoj mjeri konkretno razradila različite postojeće prostore/strukture suodgovornosti i predložila ustanovljenje novih u okviru kojih laici mogu i moraju dati svoj neprocjenjiv doprinos u izgradnji crkvenoga zajedništva. Na poseban način istaknula je strukture u koje je poželjno uključiti vjeroučitelje kako bi ih obogatili svojom teološkom stručnošću i pastoralnim iskustvom.

\subsection{IsKUSTVO ŽUPNOGA ZAJEDNIŠTVA}

Ma koliko god strukture bile dobro zamišljene i konkretno izgrađene, ako ih njihovi subjekti nedovoljno poznaju ili ih pak ne doživljavaju kao svoje, potencijal struktura ostaje neiskorišten, a njih se počinje percipirati kao udaljene, nerazumlji- 
ve i suvišne. Naime bitan čimbenik za ostvarenje zadanoga cilja neke strukture jest strukturni kapital i pripadajuća mu organizacijska kultura ${ }^{27}$. Ta vrsta kapitala odnosi se na postojani sustav stavova, vrijednosti, normi, pravila, odnosa, shvaćanja, uvjerenja - svega onoga što povezuje članove i pruža im osjećaj smisla i pripadnosti nekoj organizaciji. Vrijednost organizacijske kulture očituje se u sklonosti i prihvaćanju određenoga načina ponašanja, što kod članova stvara osjećaj identifikacije s organizacijom, motivira ih da budu kreativni, inovativni i produktivni te da se lakše predaju zadanim obvezama. Odnosno, u one strukture koje se prepoznaju kao svoje, kao one u kojima se susreću sebi slični, u kojima se mogu ostvariti vlastiti potencijali, koje odišu uzajamnošću i zajedništvom u njih se rado i uključuje i u njima se rado djeluje, one tada žive i povratno doprinose dodatnoj izgradnji zajedništva. Pojedinac tako može biti izuzetno prikladan za obavljanje određenoga posla, međutim, ako organizacija u nekom dijelu nema jasno identificirane smjernice za ostvarivanje ciljeva te ima slabe sustave i procedure za komunikaciju i praćenje aktivnosti članova, cjelokupni ljudski kapital ne će iskoristiti svoj cjelovit potencijal, a organizacija ne će ostvariti zadani cilj. Duboko svjesna važnosti izgradnje zajedništva kao sadržaja, metode i, konačno, cilja ukupne obnove, Sinoda će na više mjesta posebno istaknuti nužnost razvoja postojećih i izgradnje novih struktura, oblika i sadržaja koji će zajedništvo župne, ali i ukupne mjesne Crkve njegovati i dodatno izgrađivati ${ }^{28}$. Na tragu toga posebno je važno u župi, kao temeljnoj stanici zajedništva kršćanskoga života i jezgri pastoralnoga djelovanja, ${ }^{29}$ promicati klimu radosti, zajedništva i suodgovornosti, koja će postupno postajati privlačna i poželjna i za one koji ostaju na rubu crkvenoga zajedništva ${ }^{30}$. Prosječna ocjena svih anketiranih na pitanje o zadovoljstvu vlastitom župom kao kršćanskom zajednicom iznosi 3,3. Premda je pohvalno što ni jedan vjeroučitelj ne ocjenjuje zajedništvo svoje župe ocjenom jedan, a tek njih 14,7 \% ocjenom dva, ipak je vrlo mali broj onih koji ju ocjenjuju ocjenom pet $(6,7 \%)$. Najveći je broj onih koji ga ocjenjuju ocjenama četiri $(38,6 \%)$ i tri $(40,0 \%)$. Te ne baš previsoke ocjene percepcije župnoga zajedništva postaju u određenoj mjeri i razumljive kada ih se promotri u odnosu na odgovore na pitanje o postojanju i ostvarenju konkretnih oblika/struktura izvan euharistijskoga druženja župljana, a čije organiziranje Sinoda upravo zahtijeva. Taj se zahtjev na poseban način odnosi na prezbitere i druge pastoralne radnike. Na nji-

\footnotetext{
${ }^{27}$ Usp. D. SUNDAĆ, N. ŠVAST, Intelektualni kapital. Temeljni čimbenik konkurentnosti poduzeća, Zagreb, 2009., 38-42.; M. TANTARDINI, A. KROLL, The Role of Organizational Social Capital in Performance Management, u: Public Performance \& Management Review, https://www.lafollette. wisc.edu/images/publications/PIP/Tantardini_Kroll_PPMR.pdf

${ }^{28}$ Usp. Izjave i odluke, br. 13, 30, 340, 554 i 575.

${ }^{29}$ Usp. isto, br. 554.

${ }^{30}$ Usp. isto, br. 30 .
} 
ma je da razrade i druge sadržaje osim liturgijskih kojima bi kršćani i župna zajednica na sebi vlastit način mogli svetkovati nedjelju, a što konkretno uključuje različite oblike razonode, duhovne formacije, posjećivanja bolesnika i invalida, druženja mladih bračnih parova, športskih aktivnosti, natjecanja i različitih oblika zabave ${ }^{31}$. Dok $41,3 \%$ vjeroučitelja tvrdi da na području njihove župe postoji najmanje jedan oblik druženja nakon nedjeljne mise, više od polovice $(52,0 \%)$ tvrdi da ne postoji ni jedan, a njih 6,7 \% čak ni ne zna postoji li ili ne postoji. Najprisutniji oblik druženja jest druženje pjevača/čitača sa župnikom i/ili kapelanom (44,0 \%), zatim slijede kratka druženja poslije mise namijenjena svima na koje pozivaju župnik i/ili kapelan $(26,0 \%)$, određen broj obitelji poslije mise druži se privatno $(24,0 \%)$ te, nažalost, najmanje ima organiziranih druženja na kakva je pozvala Sinoda $(6,0 \%)$. Posebno zabrinjavaju odgovori na pitanje: $\gg$ Ako ne postoji nikakav oblik druženja je li do sada postojala inicijativa «, jer tek njih $38,4 \%$ zna da je postojala neuspješna inicijativa, a $61,6 \%$ ih ne zna. Od onih koji su odgovorili potvrdno da je inicijativa postojala $52,3 \%$ znaju da je bila župnikova, a $47,7 \%$ zna da je bila laikova. Opravdano je pretpostaviti da s jedne strane manjak izgrađenosti župnoga zajedništva i njegova konkretnoga ostvarenja ne će značajno negativno utjecati na vjeroučitelje koliko će na osjećaj pripadnosti, suodgovornosti i konkretnih aktivnosti ostalih laika, a napose rubnih.

\subsection{UKLJUČENOST U RAD STRUKTURA SUODGOVORNOSTI}

Suodgovorno zajedništvo i dijalog u životu župne zajednice na poseban način žive i ostvaruju se unutar župnoga pastoralnoga vijeća ${ }^{32}$. U govoru o ustrojstvu župnih pastoralnih vijeća Sinoda čini značajan iskorak u korist izgradnje zajedništva u odnosu na tada postojeći ${ }^{33}$, ali i u odnosu na današnji Pravilnik župnog pastoralnog vijeća u Đakovačko-osječkoj nadbiskupiji. Naime, dok pravilnici propisuju da vijeće u načelu ima tri odbora: Odbor za naviještanje, Odbor za liturgijski i molitveni život i Odbor za karitativnu djelatnost, Sinoda uz manje bitne terminološke razlike navodi i četvrti, a za ostvarenje sinodske obnove možda i najvažniji - Odbor za izgradnju zajedništva ${ }^{34}$. Taj sinodski zahtjev treba ozbiljno uzeti u obzir u nekim budućim izmjenama i dopunama Pravilnika jer će se tako ne samo ispuniti slovo Si-

\footnotetext{
${ }^{31}$ Usp. isto, br. 340.

${ }^{32}$ Usp. isto, br. 573.

${ }^{33} \mathrm{Za}$ detaljniji uvid u terminološku i sadržajnu razliku između pravilnika i Izjava i odluka vidjeti u: Odluka biskupa Ćirila Kosa od 15. svibnja 1988., br. 981/1988. Odluku je potvrdio biskup Marin Srakić okružnicom od 4. lipnja 1997., br. 1100/1997. Također usp. Pravilnik župnog pastoralnog vijeća u Đakovačko-osječkoj nadbiskupiji, u: Vjesnik dakovačko-osječke nadbiskupije i Srijemske biskupije 139(2011.)1-2, 113-114.

${ }^{34}$ Usp. Izjave i odluke, br. 575.
} 
node već ponajprije ozbiljno strukturno doprinijeti dodatnoj izgradnji zajedništva u župama. U župnom pastoralnom vijeću treba biti barem jedan vjeroučitelj koji živi na području župe ${ }^{35}$. Njegova će osobita zadaća biti promicanje bolje suradnje i koordinacije između škole i župe te između ostalih vjeroučitelja sa župnikom, suradnicima u župnoj katehezi i ostalim župnim suradnicima ${ }^{36}$. Od ukupnoga broja anketiranih vjeroučitelja 46,6 \% članovi su župnoga pastoralnoga vijeća. Da odgovornost u župi za suradnju škole i župe treba preuzeti župnik u suradnji s vjeroučiteljima smatra od ukupnoga broja anketiranih njih $57,3 \%$, a 70,6 \% ih je spremno takvu zadaću i preuzeti, a trenutačno ju i preuzima njih 46,6\%. Slični, vrlo pohvalni podatci jesu i za preuzimanje odgovornosti za odnos župne kateheze i školskoga vjeronauka, $61,3 \%$ ih smatra da tu zadaću treba preuzeti župnik u suradnji s vjeroučiteljima, a spremni su je preuzeti njih $73,3 \%$, a trenutačno ju preuzima njih 52,0\%. Veća spremnost na uključivanje od stvarno ostvarenih aktivnosti $\mathrm{s}$ jedne strane ukazuje na pohvalnu osviještenost vjeroučitelja u njihovim odgovornostima, ali s druge strane, kako bi se povećala konkretna djela suodgovornosti vjeroučitelja, potrebno je tragati za razlozima koji dovode do manje aktivnosti od spremnosti na aktivnost.

Radi ostvarenja poosobljenijega pristupa u pastoralnom djelovanju Sinoda izriče potrebu da se na razini župa nastavi s oblikovanjem više skupina vjernika ${ }^{37}$ koje će dinamičnije ostvarivati program korjenite obnove te tako dodatno poticati vjerničku zauzetost unutar i izvan župne zajednice ${ }^{38}$. Od ukupnoga broja anketiranih vjeroučitelja njih 67,5 \% članovi su u barem jednoj od ukupno anketom 14 popisanih vjerničkih skupina u župi. Najviše vjeroučitelja uključeno je u različite skupine sakramentalne kateheze $(42,9 \%)$, a izrazito manje u zbor (14,3\%), čitače (11,0\%), karitas (7,7\%), biblijsku skupinu (6,6\%), misijsku skupinu (5,5\%), skupinu mladih $(3,3 \%)$, ministrante $(2,1 \%)$ te najmanje u župno dopisništvo $(1,1 \%)$, liturgijsku skupinu (1,1\%), Katoličku malonogometnu ligu (1,1\%), Franjevački svjetovni red $(1,1 \%)$, uređenje crkve $(1,1 \%)$ i Vjeru i svjetlo $(1,1 \%)$. Velik broj vjeroučitelja uključenih u sakramentalnu katehezu jest samo dodatna potvrda o već prije u ovom radu spomenutim pastoralnim interesima. Dakako da ni u kom slučaju nije problem jer su vjeroučitelji uključeni u sakramentalnu katehezu, ali jest problem izrazit manjak njihove uključenosti u neke druge župne skupine koje su time u određenoj mjeri osiromašene jer bi i u njima mogli značajno doprinijeti svojom kreativnošću, pastoralnim iskustvom, a napose teološkom stručnošću.

\footnotetext{
${ }^{35}$ Usp. isto, br. 577.

${ }^{36}$ Usp. isto, br. 154.

${ }^{37}$ Usp. isto, br. 565 .

${ }^{38}$ Usp. isto, br. 556.
} 
Sinoda je prepoznala i preporučila i one strukture suodgovornosti koje su nastale slobodnim inicijativama vjernika laika izvan okvira župnih zajednica, a koje se u crkvenopravnom okviru nazivaju vjernička društva ${ }^{39}$, a u građanskopravnom udruge civilnoga društva ${ }^{40}$. Radi jednostavnosti prikaza u nastavku rada koristit ćemo se pojmovima vjernička udruga kada mislimo na bilo koji oblik udruženoga djelovanja vjernika laika, a ne-vjernička udruga kada mislimo na ostale udruge civilnoga društva ${ }^{41}$. Snaga i zauzetost članova vjerničkih udruga velik je pastoralni potencijal koji trebaju prepoznati i promicati sve nadbiskupijske strukture i svi pastoralni djelatnici kako bi se njihovo djelovanje uklopilo u ostvarenje zajedničkoga evangelizacijskoga poslanja ${ }^{42}$. Sinoda od vjerničkih udruga posebno zahtijeva da urede svoj crkvenopravni i građanskopravni status ${ }^{43}$ te ih potiče da svoj rad predstavljaju i kao društveno koristan te se povezuju sa srodnim udrugama civilnoga društva i javnim ustanovama. Na području uključivanja vjeroučitelja u djelovanje vjerničkih udruga uočljiva je značajna razlika između njihove spremnosti na uključivanje i konkretne uključenosti. Čak 90,5 \% vjeroučitelja izražava spremnost da udruženo s drugima sudjeluje u promicanju kršćanskih vrijednosti u hrvatskom društvu, ali je istodobno tek njih 20,2 \% uključeno u rad u nekoj vjerničkoj civilnoj udruzi. Zanimljivo je da je dvostruko veća, ali ipak još uvijek i nedovoljna uključenost u ne-vjerničke udruge (42,6\%). Što je privlačnije u ne-vjerničkim udrugama od vjerničkih, zašto se vjeroučitelji više pronalaze u njihovu djelovanju, jesu pitanja za čijim se odgovorima mora neizostavno tragati u budućem pastoralnom planiranju na razni Nadbiskupije. Na ta se pitanja mora napose odgovoriti i zbog činjenica da svi anketirani vjeroučitelji (100 \%) izražavaju spremnost pomoći onima koji nisu dio njihove obitelji ili prijatelja te da ih je čak 93,3\% koji su u posljednja dva mjeseca barem jednom nekome pomogli. Kako i zašto su vjeroučitelji nasuprot brojčano slaboj uključenosti u organizirano djelovanje pojedinačno vrlo aktivni? Ta pitanja uz ozbiljne sociološke razloge poput praktične koristi udruženoga djelovanja u odnosu na kompleksnost društvenih problema sadrže i mnogo ozbiljnije i važnije ekleziološke razloge jer organizirano udruženo djelovanje izvrsno odgovara položaju vjer-

\footnotetext{
${ }^{39}$ Usp. IVAN PAVAO II. (proglasio), Zakonik kanonskoga prava, u: F. KUHARIĆ (odobrio), Codex iuris canonici fontium annotatione auctus, Zakonik kanonskoga prava sizvorima, Zagreb, 1996., kanon $298-329$.

${ }^{40}$ HRVATSKI SABOR, Zakon o udrugama, u: Narodne novine, od 18. lipnja 2014. (2014) 74.

${ }^{41}$ Više o podjeli i o odnosu pojmova vjerničko društvo i civilna udruga vidi: I. JAKOBFI, Imamo li svijest društvene odgovornosti? u: Vjesnik Đakovačko-osječke nadbiskupije i Srijemske biskupije 139(2011.)1-2, 27.

${ }^{42}$ Usp. Izjave i odluke, br. 176. i 178.

${ }^{43}$ Usp. isto, br. 177 i 179.
} 
nika i ujedno je znak zajedništva i jedinstva Crkve u Kristu ${ }^{44}$. Sva nabrojena pitanja dodatno će dobiti na značaju i urgentnosti ako ih promotrimo na temelju podataka o konkretnim volonterskim aktivnostima i područjima volontiranja.

\subsection{VOLONTERSKO ZALAGANJE KAO PRIGODA ZA NOVE OBLIKE PASTORALNOGA ZALAGANJA}

Sinoda na više mjesta progovara o subjektima, obvezi, oblicima i strukturama volontiranja ${ }^{45}$. Svi crkveni djelatnici i suradnici pozvani su svoju službu promatrati ponajprije kao osobni odgovor na Božji poziv. Pozvani su rasti u duhu radosne dragovoljnosti te prije svega svojim primjerom razvijati duh volonterstva ${ }^{46}$. Posebno se potiče vjeroučitelje da prepoznaju da je bitna dimenzija njihova identiteta volonterski rad u vjerničkim udrugama ${ }^{47}$, ostalim udrugama civilnoga društva ${ }^{48}$ i napose u župi ${ }^{49}$. Sinoda se obraća i župnicima osvješćujući ih da je volonterski pristup u župi moguće sačuvati samo ako pastoralni djelatnici svojoj službi pristupaju s entuzijazmom i ljubavlju te ako znaju poštovati realne granice u svojim očekivanjima od volonterskih suradnika ${ }^{50}$, što bi u vremenskim okvirima iznosilo oko jedan sat tjedno ${ }^{51}$. Od ukupnoga broja anketiranih vjeroučitelja ${ }^{52}$ najveći broj ih volontira u župi (77,3 \% - 1,9 sati tjedno), zatim u školi (49,3\% - 2,4 sata tjedno), ne-vjerničkoj udruzi (29,3\% - 1,9 sati tjedno), vjerničkoj udruzi (24,0 \% 2,5 sati tjedno), Nadbiskupiji (16,0 \% - 1,7 sati tjedno) te u nekoj drugoj organizaciji $(9,3 \%-3,7$ sati tjedno). Od anketiranih vjeroučitelja ukupno ih volontira $96,0 \%$ prosječno 4,8 sati tjedno. Koliko god ti podatci o udjelu vjeroučitelja i njihovih tjednih volonterskih sati bili pohvalni, ipak, kada je riječ o volontiranju u školama, u određenoj mjeri graniče s nepravdom. Koliko god nekoga nosio evangelizacijski zanos, ipak, iz perspektive ostalih zaposlenika škole upitno je treba li vjeroučitelj volontirati u organizaciji u kojoj za svoj rad kao i drugi zaposlenici prima plaću. Naime, gledano

${ }^{44}$ DRUGI VATIKANSKI KONCIL, Dekret o apostolatu laika $\gg$ Apostolicam actuositatem $\ll$, u: ISTI, Dokumenti, Zagreb, 1993., br. 18 i 19.

${ }^{45}$ Usp. Izjave i odluke, br. 27, 77, 79, 89, 157, 159, 169, 174, 205, 252, 254, 519, 564, 569, 572, 692 i 710 .

${ }^{46}$ Usp. isto, br. 692 i 710.

${ }^{47}$ Usp. isto, br. 157.

${ }^{48}$ Usp. isto, br.169.

${ }^{49}$ Usp. isto, br. 154.

${ }^{50}$ Usp. isto, br. 252.

${ }^{51}$ Usp. isto, br. 254.

${ }^{52}$ Pod pretpostavkom da neki vjeroučitelji volontiraju u nekoliko organizacija ostavljena im je mogućnost navesti više organizacija volontiranja. 
iz perspektive svijeta kojemu je Crkva poslana, ako netko uz redovite radne obveze obavlja volonterski rad u radnoj organizaciji u kojoj je zaposlen, tada se izlaže riziku da na neizravan način u očima ostalih zaposlenika koji bez volontiranja odgovorno obavljaju svoje poslovne zadatke bude percipiran kao nelojalna konkurencija, što ni $\mathrm{u}$ kom slučaju iz pastoralne perspektive nije poželjno. $U$ današnjem socioekonomskom kontekstu, kada se zaposlenici u javnom sektoru u velikoj mjeri opravdano zalažu za dostojnije uvjete rada, primjerenije radno opterećenje i pravedniju plaću, poslovni odnosi s jedne strane poslodavac - posloprimac/volonter (vjeroučitelj) i s druge strane posloprimac (ostali nastavnici) - posloprimac/volonter (vjeroučitelj) nisu i ne smiju se shvaćati kao puki poslovni/svjetovni fenomeni. Naime oni upravo zato što su svjetovni, jer je nemoguće razdvojiti razinu stvorenja od razine otkupljenja ${ }^{53}$, imaju povrh svega teološki i evangelizacijski značaj. Sve ono što se tiče zajednice ljudi, poput stanja i problema koji se odnose na pravdu, nije strano evangelizaciji i ona ne bi bila potpuna ako ne bi vodila računa o uzajamnom apelu što ga jedan drugomu stalno upućuju evanđelje i konkretni društveni život čovjeka. ${ }^{54} \mathrm{U}$ slučaju školskoga vjeroučiteljskoga volontiranja taj su apel dugogodišnja zalaganja za pravednije uređenje položaja zaposlenika u javnom sektoru, koja država i šira javnost nerijetko ismijava i ne prihvaća, a volontiranjem vjeroučitelja u školi postaju dodatno indirektno delegitimirana. Vjeroučitelji na to moraju biti posebno obazrivi jer u školi ne predstavljaju samo sebe već i ostale vjeroučitelje i Crkvu ukupno, a o kojima bi zbog njihova neopravdanoga volontiranja drugi zaposlenici mogli razvijati negativnu percepcija o socijalnoj osjetljivosti/neosjetljivosti Crkve, a samim time i neautentičnosti življenja oslobađajuće poruke evanđelja ${ }^{55} \mathrm{u}$ odnosu na nepravedne strukture ${ }^{56}$.

Slično je i s količinom volonterskih sati koji u nekim slučajevima graniče s plaćenom zaposlenošću. Od šest tipova organizacija u kojima prema rezultatima ankete vjeroučitelji volontiraju u svih šest pojavljuje se određen broj onih koji volontiraju čak četiri i više sati tjedno. Od broja vjeroučitelja koji volontiraju u nekoj organizaciji njih $12,0 \%$ volontira četiri i više sati u župi, vjerničkoj udruzi $27,7 \%$, ne-vjerničkoj udruzi 18,1 \%, Nadbiskupiji 18,1 \%, školi $24,3 \%$ i u nekoj drugoj organizaciji $42,8 \%$. Na pitanje o broju organizacija u kojima volontiraju $4 \%$ vjeroučitelja odgovara da ne volontira ni u jednoj organizaciji, $29,3 \%$ u jednoj, 34,7 \% u dvjema, $14,7 \%$ u trima, $13,3 \%$ u četirima, $2,7 \%$ u pet i u šest i više organizacija $1,3 \%$. Uz

\footnotetext{
${ }^{53}$ Usp. PAPINSKO VIJEĆE »IUSTITIA ET PAX «, Kompendij socijalnog nauka Crkve, Zagreb, 2005., br. 66.

${ }^{54}$ Usp. Isto, br. 66.

${ }^{55}$ Usp. Isto, br. 67-68.

${ }^{56}$ Usp. Isto, br. 119-123 i 193.
} 
toliku veliku količinu volontiranja očito se $\mathrm{u}$ određenoj mjeri nepravda čini i vlastitoj obitelji koja je kućna Crkva i kao takvu ju se ne smije izgubiti iz vida ni u individualnim ni u udruženim pastoralnim nastojanjima. Jedan od bitnih preduvjeta zdravoga volonterskoga okružja jest primjeren zakonodavni okvir koji će ga poticati, podržavati i štititi ${ }^{57} \mathrm{i}$ postojanje srednjega staleža koji je prikladno materijalno osiguran te ima dovoljno sposobnosti i znanja za rad na korist općega dobra ${ }^{58}$. Važeći hrvatski volonterski zakonodavni okvir ${ }^{59}$, iako u mnogo čemu nedovoljno dorečen i ograničavajući, sadrži vrlo pohvalne odredbe. Zakon o volonterstvu obvezuje sve organizatore volontiranja, pa tako i sve naše župe i vjerničke udruge, da nadležnom ministarstvu podnose godišnja izvješća o volonterima i njihovim aktivnostima. Ovdje nije riječ samo o pukoj odredbi zakonodavca već o instrumentu po kojem projekti i konkretna djelovanja pojedinih organizacija stječu društveni legitimitet koji je Crkvi pastoralno izuzetno bitan kako bi poslanje kojemu je vjerna bilo prikladno društveno vrjednovano, a posljedično tomu i poželjno. Prema podatcima dostupnim u Odjelu za volonterstvo pri Ministarstvu za demografiju, obitelj, mlade i socijalnu politiku od ukupnoga broja prijavljenih organizatora volontiranja na području Republike Hrvatske tek jedan neznatan broj jesu župe i karitasi: godine 2014. - 1032 organizatora volontiranja, od toga 0 župa od ukupno $1559^{60}$ (Đakovačko-osječka nadbiskupija 0 župa) i 7 karitasa od ukupno 16 (Đakovačkoosječka nadbiskupija 0 karitasa); godine 2015. - 1367 organizatora volontiranja, od toga 16 župa od ukupno 1560 (Đakovačko-osječka nadbiskupija 1 župa) i 9 karitasa od ukupno 18 (Đakovačko-osječka nadbiskupija 0 karitasa); godine 2016. - 1217 organizatora volontiranja, od toga 1 župa od ukupno 1560 (Đakovačkoosječka nadbiskupija 0 župa) i 7 karitasa od ukupno 18 (Đakovačko-osječka nadbiskupija 0 karitasa). Neupitno je da ti podatci o župama i karitasima ni približno ne opisuju stvarno stanje, ali su oni kao takvi službeni javni podatci na temelju kojih se procjenjuje mjera doprinosa pojedinih institucija izgradnji općega dobra. Riječ je o velikom pastoralnom potencijalu koji se u budućem pastoralnom planiranju svakako mora bolje upotrijebiti na korist društvenoga ugleda Crkve, ali i zbog izražavanja primjerenoga vrjednovanja i zahvalnosti spram onih koji volontiraju. Raspodjelom podataka o broju vjeroučitelja volontera prema statusu zaposlenosti i prosječnoj tjednoj količini volonterskih sati proizlazi da su zaposleni vjeroučitelji volonterski

\footnotetext{
${ }^{57}$ Usp. HRVATSKI SABOR, Zakon o izmjenama i dopunama Zakona o volonterstvu, u: Narodne novine, od 22. veljače 2013., br. 22.; HRVATSKI SABOR, Zakon o udrugama, u: Narodne novine, od 18. lipnja 2014., br. 74.

${ }^{58}$ Usp. Izjave i odluke, br. 169.

${ }^{59}$ Usp. HRVATSKI SABOR, Zakon o izmjenama i dopunama Zakona o volonterstvu, u: Narodne novine, od 22. veljače 2013., br. 22. čl. 27.

${ }^{60}$ Usp. Evidencija pravnih osoba Katoličke Crkve u Republici Hrvatskoj, https://uprava.gov.hr/evidencija-pravnih-osoba-katolicke-crkve-u-republici-hrvatskoj/830
} 
najaktivniji po količini volontera, a privremeno zaposleni po količini volonterskih sati. Od ukupnoga broja stalno zaposlenih volontira njih $98,1 \%$ prosječno 3,8 sati tjedno, od privremeno zaposlenih 88,8 \% izuzetno velikih 9,4 sata tjedno te od nezaposlenih 84,6 \% 5,8 sati tjedno. Posebno veliko značenje u pozitivnom ocrtavanju vjeroučiteljskoga potencijala u perspektivi spremnosti na volonterski rad imaju nezaposleni, koji, premda su u većoj ili manjoj mjeri materijalno nesigurni, ne zatvaraju se u vlastite životne teškoće, već svojim volonterskim aktivnostima svjedoče nesebičan evangelizacijski zanos doprinoseći razvoju Crkve i društva. Nažalost, sve je veći broj vjeroučitelja koji zbog različitih objektivnih, a ponajprije demografskih i ekonomskih razloga ne će još barem neko vrijeme moći računati na stalno zaposlenje. Vjeroučitelji ukupno jesu relativno mlada populacija koja još barem nekoliko godina ne će u većem broju početi odlaziti u mirovinu, a mogućim nekim novim mirovinskim reformama to bi se moglo još dodatno produljiti. Također $\mathrm{u}$ našim je školama sve manje učenika, a posljedično i potražnja za nastavnicima, a prema tomu i potražnja za vjeroučiteljima. Te i slične pojave ne bi smjele postati razlogom većega odljeva teologa laika u neka druga zanimanja, već, naprotiv, poticaj na kreativnost u pronalaženju novih pastoralnih modela koji će im omogućiti zapošljavanje/ samozapošljavanje. U protivnom štetu ne će samo osjetiti osobno teolozi laici u neostvarenju vlastitoga životnoga poziva već i ukupna mjesna Crkva izgubivši prigodu da velik pastoralni potencijal usmjeri prema ostvarenju Sinodom zahtijevanim uključivanjem u aktualna prioritetna pastoralna područja. Jedno od mogućih rješenja jest zapošljavanje/samozapošljavanje u sektoru civilnoga društva kroz socijalno zagovaranje i neprofitno pružanje socijalnih usluga, a što je ujedno posebno prikladan model za ostvarenje verbalne i djelatne solidarnosti. Verbalna solidarnost jest jasno i glasno izjašnjavanje i zauzimanje stava u javnosti u prilog na bilo koji način obespravljenima i ugroženima. ${ }^{61}$ Pod drugom, djelatnom solidarnošću smatraju se svi oni zahvati u ona područja socijalnoga u kojima se nije dovoljno samo verbalno zauzeti već i konkretno djelovati radi pomoći najugroženijima. ${ }^{62}$ Neprofitne organizacije postaju sve više dio novoga modela socijalne politike $u$ okviru kojega na poseban način dolazi do izražaja djelatna solidarnost pretočena u socijalno poduzetništvo, poznato pod nazivom kombinirani model socijalne politike (welfare mix $)^{63}$. Razvoj ovoga modela značajnim se dijelom temelji na kritici do-

${ }^{61}$ Usp. Š. MARASOVIĆ, Porijeklo i sadržaj pojma »solidarnost«, u: Bogoslovska smotra 74(2004.)2, 371.

${ }^{62}$ Usp. isto, 371.

${ }^{63}$ Više o tom modelu vidi u: G. BEŽOVAN, Mogućnosti razvoja modela kombinirane socijalne politike u Hrvatskoj, u: Revija za socijalnu politiku 2(1995.)3, 195-214.; ISTI, Mogućnosti razvoja modela kombinirane socijalne politike u Hrvatskoj, u: Revija za socijalnu politiku 7(2000.)3, 289-298.; L. DADIĆ, Važnost fundreisinga za održivost neprofitnih organizacija, u: Oeconomica Jadertina (2016.)2, 103-116. i D. VIDOVIĆ, Socijalno poduzetništvo u Hrvatskoj. Doktorski rad, Zagreb, 2012. 
minantne uloge države i njezinih ustanova u javnom zagovaranju i pružanju socijalnih usluga siromašnima, starima, nemoćnima, napuštenima, zlostavljanima... Državni socijalni programi nerijetko su zbog naravi države birokratizirani, neučinkoviti te neinovativni. Istodobno neprofitne organizacije imaju sve značajniju ulogu u pružanju socijalnih usluga, pri čemu je naglasak stavljen na sufinanciranje i suradnju lokalne i državne vlasti. Pružene usluge postaju primjerenije korisnicima te se nastoji ostvariti načelo pokrivanja troškova usluga iz različitih izvora, što dodatno osigurava financijsku stabilnost. Premda je riječ o neprofitnom sektoru, on ne isključuje mogućnost zapošljavanja, već ga, dapače, zahtijeva kao bitan preduvjet uspješnoga pružanja socijalnih usluga. Duboka osviještenost vjeroučitelja za nužnost zalaganja i konkretnoga pomaganja drugima, spremnost na različit volonterski rad na korist izgradnje općega dobra, teološka stručnost i komunikacijske vještine stečene tijekom studija teologije kao humanističke znanosti te spremnost na samostalnu i organiziranu permanentnu edukaciju jesu bitni preduvjeti koji omogućuju da sadašnji i budući nezaposleni teolozi laici svoj vjeroučiteljski poziv počnu ostvarivati na području kombiniranoga modela socijalne politike. Dobrobit ne bi imali samo vjeroučitelji rješavanjem problema moguće nezaposlenosti već: ukupna mjesna Crkva jer je u svome krilu sačuvala vjeroučiteljski pastoralni potencijal i prikladno ga usmjerila prema novim pastoralnim područjima te po inovativnom karitativnom djelovanju $\mathrm{u}^{64}$ i socijalnom zagovaranju ${ }^{65}$ koje ga prati, konkretno ostvarila je svoje poslanje na današnjem društvu prihvatljiv i razumljiv način; ugrožene i marginalizirane društvene skupine, kao one čiji se problemi dodatno aktualiziraju u javnosti i konkretni korisnici socijalnih usluga zbog sigurnijega i stabilnijega podizanja kvalitete života s pomoću onih koji su već sami po sebi skloni besplatnom pomaganju drugima te zato na njih mogu računati i u trenutcima manjka nužnih financijskih sredstava; napose bi se doprinijelo razvoju općega dobra ukupnoga hrvatskoga društva.

\section{Prema dvadesetoj obljetnici objave Izjava i odluka}

Rezultati provedenoga istraživanja zahtijevaju da, utemeljeno na njima i s pogledom usmjerenim prema budućnosti, izdvojimo konkretne praktične smjernica koje bi trebale pozitivno doprinijeti dodatnom ostvarenju zahtijevane sinodske obnove Đakovačko-osječke nadbiskupije.

Polazište i prioritet od kojega se mora već danas započeti jest dodatno ojačavanje postojećih struktura suodgovornosti. U okviru toga mora se izraditi plan temeljitijega upoznavanja svećenika i vjeroučitelja laika sa sinodskim zahtjevima, njihova

\footnotetext{
${ }^{64}$ Usp. Izjave i odluke, br. 213.

${ }^{65}$ Usp. isto, br. 208.
} 
oduševljavanja i konkretnoga praktičnoga ostvarenja sinodskih zahtjeva te dinami$\mathrm{ku}$ vremenske procjene učinjenoga u kratkoročnom (jedna godina), srednjoročnom (dvije do tri godine) i dugoročnom (deset godina) razdoblju. Za svako razdoblje procjene potrebno je izraditi plan očekivanoga i kriterije mjerenja učinjenoga kako bi se po isteku pojedinoga razdoblja moglo procijeniti što jest, a što još treba učiniti i kako. Pri tome se posebnu pozornost mora posvetiti ostvarenju sljedećega u odnosu na:

- Nadbiskupiju, da kod moguće buduće izrade novoga pravilnika župnoga pastoralnoga vijeća uvrsti obvezu ustanovljenja odbora za izgradnju zajedništva te tako dodatno strukturno potakne sinodsku obnovu u smjeru izgradnje župnoga i ukupnoga crkvenoga zajedništva.

- Svećenike, u okviru njihove permanentne edukacije izraditi model kako im dodatno osvijestiti da su oni kod najvećega broja laika prvi izvor upoznavanja sa sinodskim zahtjevima te da je zbog toga njihovo zalaganje oko sinodske obnove na župnoj razini presudno važno. Da su kao odgovorne osobe u župama kao organizatorima volontiranja zakonom obvezni podnositi nadležnom ministarstvu godišnja izvješća o volonterskim aktivnostima te da će tako s jedne strane prikladno vrjednovati volonterski rad, a s druge doprinijeti društvenom legitimitetu poslanja Crkve.

- Laike (studente teologije i nezaposlene teologe) već tijekom studija, ali i u sklopu permanentne edukacije teoretski i praktično pripremati za kompleksnost današnjih demografskih i ekonomskih dinamizama koji negativno utječu na potražnju nastavničkoga kadra. Također dodatno ih osvještavati da današnji pastoralni prioriteti zahtijevaju nove pristupe u percepciji konkretnoga ostvarenja vjeroučiteljskoga poziva aktivnim uključivanjem u društvenu stvarnost, koja pozitivno povratno omogućuje izradu različitih modela samozapošljavanja u sektoru civilnoga društva. Na tragu toga poželjno bi bilo sadašnjim i budućim studentima teologije u okviru katedre socijalnoga nauka Crkve ponuditi izborni kolegij iz socijalnoga poduzetništva.

- Laike (vjeroučitelje), nastavno na već rečeno za studente i nezaposlene, izraditi model po kojem će biti dublje upoznati sa sinodskim učenjem te pri tome posebnu pozornost obratiti na veliki potencijal koji se krije u njihovu povjerenju spram kolega vjeroučitelja i svećenika. Također poticati ih da se uz župni katehetski rad uključuju u postojeće i potiču stvaranje novih župnih struktura suodgovornosti, ali istodobno uvažavajući i njihovu vrlo prisutnu volontersku preopterećenost. 


\section{Zaključak}

U radu su predstavljeni i analizirani rezultati anketnoga istraživanja o stanju i perspektivama laikata u postsinodskom vremenu, a s posebnim osvrtom na vjeroučitelje laike radi traganja za odgovorima na pitanja: Koliko je Sinoda zaživjela u svijesti i djelovanju vjeroučitelja laika? Kakav je današnji vjeroučiteljski potencijal s kojim Nadbiskupija raspolaže u perspektivi budućih pastoralnih programa? Kao ciljana skupina izabrani su vjeroučitelji laici starosne dobi do 45 godina zbog svojega specifičnoga pastoralnoga položaja u Crkvi, očekivane prikladne educiranosti o teološko-pastoralnom značaju instituta sinode i uključenosti u provedbu same Sinode te starosne prikladnosti za moguće buduće planiranje i u djelo provođenje ozbiljnih dugoročnih pastoralnih planova.

Na temelju učinjene analize zaključujemo i kao pastoralne smjernice preporučamo sljedeće:

- Vjeroučitelji do 45 godina starosti visoko su motivirana i pastoralno vrlo aktivna populacija vjernika koja svoj vjeroučiteljski položaj u Crkvi ponajprije doživljava kao poziv, a tek drugotno kao profesiju te ih kao takve možemo opisati kao velik, nezamjenjiv, ali istodobno i nedovoljno iskorišten potencijal.

- Izrazito malen broj vjeroučitelja zainteresiran je za ona pastoralna područja koja je Sinoda identificirala kao prioritetna. Razlog tomu jest u manjku dobro programirane i organizirane strukturne skrbi za njegovanje i rast vjeroučiteljskoga poziva u skladu sa sinodskim zahtjevima.

- Polazište od kojega se mora započeti kako bi se dodatno ostvarila zahtijevana sinodska obnova jest dodatno ojačavanje postojećih struktura suodgovornosti. U okviru toga potrebno je izraditi plan temeljitijega upoznavanja svećenika i vjeroučitelja laika sa sinodskim zahtjevima, njihova oduševljavanja i konkretnoga praktičnoga ostvarenja sinodskih zahtjeva te dinamiku vremenske procjene učinjenoga u kratkoročnom (jedna godina), srednjoročnom (dvije do tri godine) i dugoročnom (deset godina) razdoblju. 


\title{
THE STATE AND PERSPECTIVES OF THE LAITY IN THE POST-SYNODAL TIME - WITH SPECIAL REFERENCE TO LAY RELIGIOUS TEACHERS
}

\author{
Igor JAKOBFI*
}

Summary: The paper came about as part of the tenth anniversary of publishing the Statements and Decisions of the Second Synod of the Diocese of Đakovo and Srijem in response to the wishes of the Synod: Namely, that every member and parish community in the Church of Đakovo and Srijem become more aware of their own identity; That the Church of Đakovo and Srijem realizes its mission through various forms of co-responsible ministry of all the baptized faithful; and that the Church of Đakovo and Srijem allows for areas of co-responsibility under its wing. Based on the results of a poll conducted among lay religious teachers the paper searches for answers to questions: To what extent has the Second Diocesan Synod become engrained in the consciousness and actions of lay religious teachers? What potential does the Archdiocese currently have at its disposal regarding religious teachers in view of future pastoral programs? In order to create an initial plan of operation based on the answers to the above questions what needs to be done in the next ten years in order to facilitate the desired synodal renewal? The first part of the paper proposes that to be a religious teacher is first and foremost a life calling, and only secondly a profession. However, the second part of the paper shows the lack of a well programed and organized structural care for nurturing and fostering that calling in the area of accepting synodal demands for the renewal of pastoral care, which caused the Synod, and its pastoral demands, to remain largely unfamiliar to many religious teachers, and consequently an unaccepted reality. Along the lines of unfamiliarity and unacceptance of synodal demands, the third part of the paper analyzes the state of concrete areas of pastoral interests and pastoral activities of religious teachers, particularly the following areas: marriage and family, media, ecumenism, culture, the social doctrine of the Church, intellectuals, as well as the elderly/the sick/the disabled. The fourth part analyzes the involvement of religious teachers in the work of three types of structures of co-responsibility; in parish pastoral councils, parish groups and religious societies, as well as the specific volunteer work, its limitations and opportunities. The final part of the paper offers practical recommendations and advice to the Archdiocese, bishops and laity (theology students, unemployed theologians, and religious teachers) on how to achieve strong structures of

* MSc. Igor Jakobfi, Catholic Faculty of Theology in Đakovo, J. J. Strossmayer University of Osijek, P. Preradovića St 17, P. O. box 54, 31400 Đakovo, Croatia, ijakofi@gmail.com 
Diacovensia 27(2019.)1

co-responsibility so that the twentieth anniversary of the Synod gets to be celebrated in a pastorally renewed atmosphere.

Keywords: Second Diocesan Synod, lay religious teachers, the laity, structures of co-responsibility. 